\title{
Correlation of self-compassion and spiritual well-being with drug craving in people with substance use disorders
}

\author{
Mahmoud Abdel Hameed Shahin ${ }^{1 *}$ (D), Shaimaa Abdelbaset Hamed ${ }^{2}$ and Samah Mohamed Taha²
}

\begin{abstract}
Background: Globally, drug abuse is a serious and exacerbating phenomenon, not only in terms of its prevalence and its impact on individuals, families, professional and social aspects but also because of its economic and medical repercussions. Cravings, the main feature of addiction, are the drivers of continued drug abuse and a return to addiction after recovery. This research aimed to explore the relationship between self-compassion and spiritual wellbeing with drug cravings. This research used a descriptive correlational study design. The study sample consisted of all accessible addiction patients who had visited the outpatient clinics or were admitted to the Addiction Unit of the Psychiatry Department at Mansoura University Hospital during a 3-month period from October to December 2020. Patients were asked to respond to questionnaires assessing self-compassion, spiritual well-being, and drug craving.

Results: The results showed that the majority of the participants had a moderate level of self-compassion and spiritual well-being. However, drug cravings were negatively related to both self-compassion and spiritual well-being.

Conclusions: People with drug addiction consistently need programs to increase their self-compassion and spiritual well-being to overcome the intensity of cravings. Improving feelings of self-compassion and spiritual well-being has a positive effect in reducing craving for substance abuse among drug-addict patients.
\end{abstract}

Keywords: Addiction, Drug craving, Self-compassion, Spiritual well-being, Substance dependence

\section{Background}

Drug addiction, a highly prevalent disorder affecting more than $10 \%$ of the world's population, is a major public health problem associated with increased mortality, morbidity, sociocultural problems, and healthcare costs [1]. Several factors may hinder maintaining drug abstinence over time. Among the most important of craving is a symptom of withdrawal and is caused by changes in neurochemicals induced by psychotropic substances; cravings may be triggered by exposure to internal or external environmental problems [2].

Many countries around the world have established national programs to regularly monitor drug use rates

\footnotetext{
* Correspondence: Mahmood81us@yahoo.com

${ }^{1}$ Nursing Department, Mohammed Al-Mana College for Medical Science, Dammam, Saudi Arabia

Full list of author information is available at the end of the article
}

within their borders and study how these rates have changed over time. Egypt, for example, began monitoring in 1994, which revealed that $6.2 \%$ of the population had previously reported using the substance at least once [3]. The second report of the National Program for Addiction Research in Egypt in 2005 revealed that 12.6\% of the population were regular users. These results highlight the growing severity of the drug abuse crisis in the country [4]. Despite these high levels of use of psychoactive substances, there were limitations in the treatment of drug abusers due to difficulties in recognizing the preventive aspects and risk factors affecting the unhealthy use of drugs [5].

Relapse and lack of control over substance abuse are major issues [6]. Post-treatment relapse of addiction is likely as the belief in craving perpetuates opioid addiction; In other words, the physiological state of craving is

\section{Springer Open}

(c) The Author(s). 2021 Open Access This article is licensed under a Creative Commons Attribution 4.0 International License, which permits use, sharing, adaptation, distribution and reproduction in any medium or format, as long as you give appropriate credit to the original author(s) and the source, provide a link to the Creative Commons licence, and indicate if changes were made. The images or other third party material in this article are included in the article's Creative Commons licence, unless indicated otherwise in a credit line to the material. If material is not included in the article's Creative Commons licence and your intended use is not permitted by statutory regulation or exceeds the permitted use, you will need to obtain permission directly from the copyright holder. To view a copy of this licence, visit http://creativecommons.org/licenses/by/4.0/. 
an indicator of drug abuse and relapse [7]. Craving for substance abuse is a strong and persistent desire to abuse drugs and produces a strong drive to pursue substance abuse and addiction [6].

Craving refers to a physical and mental state of craving for a specific psychoactive drug, which is manifested by the individual and directed to a drug previously taken [8]. Sometimes users themselves attribute their cravings to their inability to control their cravings to use drugs, which leads to burglary, theft, or fraud.

Self-compassion is a multifaceted concept that is made up of factors that promote empathy with oneself, including mindfulness, self-kindness, and common humanity. Mindfulness is the present-focused awareness of an individual's reactions to life events. Self-kindness involves being understanding and providing self-care for yourself when faced with difficulty. Common humanity indicates that all human beings face difficulties, challenges, and negative or contradictory emotions [9].

Self-compassion is a positive and emotional attitude towards self. Previous research has shown that selfcompassion is positively associated with positive effects and negatively associated with negative effects. In addition, self-compassion is an emotional adjustment technique that allows an individual to notice, tenderness, understand, and accept negative emotions with a shared sense of humanity. Therefore, during times of suffering and distress, self-sympathy helps turn negative emotions into more positive emotions [10].

Studies have shown that self-compassion is associated with much positive psychological strength. For example, people with a high level of self-compassion reported more happiness than those with a low level of self-compassion. More generally, higher levels of hope, gratitude, and positive impact are also shown. Self-compassion is often associated with emotional intelligence, wisdom, personal initiative, intellectual flexibility, curiosity, life satisfaction, and emotions of social connection-all are essential components of a fulfilling existence. In addition, selfcompassion traits are associated with independence, abilities, relationships, and self-determination [11].

Various studies suggest that aspects that promote selfcompassion may serve as protective factors for alcohol abuse. However, studies investigating these positive aspects of sympathy or self-compassion for alcohol use after treatment of substance use disorders are still needed and recommended by several studies [9].

We need to consider the different dimensions that make up humans. Spirituality and religiosity are powerful partners in people's lives and are partly responsible for helping prevent self-destructive behavior associated with substance use. Spirituality and religiosity are separate components because spirituality embraces the existential realm and human nature, provides meaning to life through feelings of hope and faith, and enhances human well-being. Religiosity, on the other hand, is an expression of spirituality characterized by the adoption of ritual values, beliefs, and customs [5].

Douaihy and Singh [12] described spiritual wellbeing as a special condition. It is linked to the positive emotions, behaviors, responses of perception, and powers associated with self and others. The individual in a state of spiritual well-being is content with identity, honesty, loyalty, pleasure, happiness, elegance, affection, respect, optimistic outlook, comfort, inner harmony, and spiritual well-being to achieve the goal. Mental health has two aspects: religious health and existential health. Religious health represents the relationship between the individual and God or eternal power, while existential well-being refers to the relationship between the individual and others surrounding him in this world, and his internal relationships [13]. In the context of drug addiction, one study found that both religiosity and spirituality are protective factors that prevent the abuse of alcohol and other drugs and are associated with improved human life skills and physical and mental health [14].

Craving is an important factor in continued alcohol and drug use, and their recurrence during abstinence [8]. Therefore, it is useful to know the factors that may cause cravings behavior in drug addicts. Therefore, this study aims to investigate the relationship between selfcompassion, mental well-being, and craving among people with substance use disorders.

\section{Methods \\ Research design and setting}

This study employed a cross-sectional descriptive research design in which the participants were asked to fill out a self-report questionnaire. The study was implemented at the addiction unit and outpatient clinics of the psychiatric department of Mansoura University Hospital due to the convenience to the researchers. This psychiatric department includes an inpatient addiction treatment unit that specializes in the treatment and rehabilitation of drug addictions and their follow-up after hospital discharge. The addiction unit includes a detoxification unit (10 beds) a rehabilitation unit (20 beds), intermediate care unit, two outpatient clinics, in addition to a gym and an entertainment hall that contains tennis and billiards tables, a video player, and a PlayStation. This department, which is a research center that supports research into the social and psychological factors that promote drug addiction, works to improve the environment to achieve the best treatment outcomes and rehabilitation plans for drug addicts in Egypt. 


\section{Participants}

A non-probability convenience sampling procedure, total sampling specifically, was used to select the study sample. Data was gathered from all accessible patients with drug addiction who had visited the outpatient clinics or who had been admitted to the inpatient unit during a period of three months from October to December 2020 at the psychiatric department of Mansoura University Hospital. Both male and female patients were included in the study sample. During the study period, 123 patients had visited the addiction unit or clinics; however, 115 clients had agreed to participate in the study and were offered the questionnaire. The number of completed questionnaires that were returned was 100, representing a response rate of $87 \%$.

\section{Inclusion criteria}

- Drug addiction patients who visited the clinics or were admitted to the inpatient unit.

- In the period from October to December 2020.

- Willing to participate in the study.

\section{Data collection tool}

Four data collection tools were used in the study:

1. Socio-demographic datasheet: gathers demographic information and drug abuse history such as age, education level, marital status, employment status, income, residence, age of drug abuse onset, how drugs were first time used, family history of drug abuse, type of drug, and number of withdrawal attempts.

2. Brief Substance Craving Scale (BSCS): a selfreporting scale consisting of four items to assess the level of craving tendency and desire of the patient for each addictive substance, which was developed by Somoza et al. [15]. This instrument measures the intensity, frequency, and length of time spent craving in the past $24 \mathrm{~h}$, using a five-point Likert scale ranging from 0 to 4 with a mean score of 0 indicating no cravings in the past $24 \mathrm{~h}$ and a mean score of 4 indicating a high tendency for drug craving. This scale is highly correlated with addiction severity scales, and its reliability tested using Cronbach's $\alpha$ was reported as 0.88 [15]. Translation and reverse translation of the tool into the Arabic language was conducted by experts; the tool was then tested for content validity and piloted before being used.

3. Spiritual Well-Being Scale (SWBS): This scale is a self-reported scale consisting of 20 items, which was developed by Ellison [16]. This study used the Arabic version of the SWBS which was translated and implemented by Musa and Pevalin [17]. This scale measures levels of spiritual well-being and consists of two subscales: a religious well-being subscale (10 items) provides a self-assessment of one's relationship with God, and an existential well-being subscale (10 items) gives a selfassessment of one's sense of life purpose and life satisfaction. The scale uses a six-point Likert scale ranging from "strongly agree" to "strongly disagree." The total scores of this scale range from 20 to 120, with higher scores indicating greater well-being. The SWBS has a high internal consistency, high reliability, and high alpha coefficients ranging from 0.83 to 0.87 [17, 18].

4. Self-Compassion Scale (SCS): the SCS was first published by Neff [19]; however, this study used the Arabic version of SCS which was developed and translated by Hacheem [20]. The scale measures the characteristics of self-compassion and consists of 26 items that measure six subscales: self-kindness, common humanity, self-judgment, isolation, mindfulness, and over-identification. Each item was rated on a five-point Likert scale $(1=$ almost never to $5=$ almost always). The total scores of this scale range from 26 to 130, with higher scores indicating greater self-compassion. The SCS has a high internal consistency, high reliability, and high alpha coefficients ranging from 0.84 to 0.86 [20]. The mean of the scores was used for the last three scales (BSCS, SWBS, and SCS) for statistical analysis and to classify the responses into categories based on a cut score.

\section{Pilot study}

Piloting the questionnaire was carried out on $10 \%$ of the estimated study sample (13 cases). The estimated study sample was calculated using the sum of outpatient and inpatient cases who had visited the drug addiction unit for the previous three months (July through September 2020). This was 130 cases, and piloting was carried out on 13 of these participants. Piloting was conducted to evaluate the applicability and clarity of the questionnaire and assessment of the feasibility of fieldwork and to detect any possible obstacles that the researcher might face that could interfere with data collection. Necessary modifications were carried out based on the pilot study findings, such as omission and modification of some questions in order to strengthen the questionnaire contents and to improve the simplicity and clarity. The pilot sample was excluded from the main study sample. The validity and reliability of the questionnaire were then tested by a jury of experts in psychiatric and mental health specialties. 


\section{Validity and reliability}

For content validity testing, the questionnaire was given to a panel of five experts of psychiatric staff members and nursing professors who reviewed the instruments for clarity, relevance, comprehensiveness, understandability, applicability, and level of difficulty. The alpha Cronbach's test was used to check the stability of the internal consistency of the instrument and was deemed acceptable for the BSCS, SWBS, and SCS at $0.81,0.84$, and 0.89 , respectively.

\section{Study procedures}

The data collection process was completed over the course of three months (October to December 2020). The electronic questionnaires were disseminated to the patients using Google Forms via a link that allowed them sufficient time to read and answer appropriately. The completed forms were collected by the researcher for statistical testing and analysis. The data were tabulated, coded, and analyzed, then descriptive and correlation statistics were performed. Missing data was not expected as all questions needed to be answered before moving on to the next question.

\section{Statistical analysis}

The data collected was organized and analyzed using the Statistical Package for Social Sciences (SPSS) version 26.0 [21]. Data were presented using descriptive statistics in the form of frequencies and percentages for the qualitative variables, and the mean and standard deviations of the quantitative variables. The Kolmogorov-Smirnov test returns a significance of less than 0.05 , indicating that the data was not normally distributed. Therefore, we used a nonparametric test for the detection of the differences. The Kruskal-Wallis test was used to identify the significance in scores' differences between groups of participants from more than two groups. On the other hand, the Mann-Whitney $U$ test was used to assess the scores' difference between two independent groups.

The Pearson correlation test was used to determine the correlation between the variables. The Pearson correlation test result was considered statistically significant at $p$ value $\leq 0.05$ and highly significant at $p$ value $\leq 0.001$.

\section{Ethical consideration}

All official permits to conduct the study have been secured from the competent authorities. All patients were made aware of the importance and purpose of this study. Written consent was obtained from all participants in the current study. All patients were informed that their participation was voluntary; and that they have the right to withdraw at any time. The confidentiality of the information obtained is guaranteed. Participants were also informed that the data collected will only be used for the purpose of the current study, as well as for their benefit.
All ethical issues related to this scientific research were considered in accordance with the Declaration of Helsinki [22]. Moreover, an official written approval letter explaining the purpose of the current study was approved in September 2020 by the Research Ethics Committee of the Faculty of Nursing at Mansoura University and the Head of the Psychiatry Department at Mansoura University Hospital.

\section{Results}

The results of the study are illustrated in eleven tables. As shown in Table 1, the total number of participants was 100 , and over half of them (55\%) were young (2029 years old), with an average age of $29.21 \pm 7.49$ years old. The vast majority were males (97\%), and just below half of them (45\%) had a secondary school education;

Table 1 Participant sociodemographic characteristics ( $N=100)$

\begin{tabular}{|c|c|c|c|}
\hline \multicolumn{2}{|l|}{ Sociodemographic data } & \multirow{2}{*}{$\begin{array}{l}\boldsymbol{n} \\
55\end{array}$} & \multirow{2}{*}{$\begin{array}{l}\% \\
55.0 \%\end{array}$} \\
\hline Age category & $20-29$ & & \\
\hline & $30-39$ & 38 & $38.0 \%$ \\
\hline & 40 and over & 7 & $7.0 \%$ \\
\hline & $M \pm S D$ & \multicolumn{2}{|c|}{$29.21 \pm 7.49$} \\
\hline \multirow[t]{2}{*}{ Sex } & Male & 97 & $97.0 \%$ \\
\hline & Female & 3 & $3.0 \%$ \\
\hline \multirow[t]{5}{*}{ Education } & Illiterate & 7 & $7.0 \%$ \\
\hline & Primary school & 4 & $4.0 \%$ \\
\hline & Secondary school & 45 & $45.0 \%$ \\
\hline & High school & 24 & $24.0 \%$ \\
\hline & University education & 20 & $20.0 \%$ \\
\hline \multirow[t]{2}{*}{ Marital status } & Single & 88 & $88.0 \%$ \\
\hline & Married & 12 & $12.0 \%$ \\
\hline \multirow[t]{2}{*}{ Occupation } & No job & 73 & $73.0 \%$ \\
\hline & Has a job & 27 & $27.0 \%$ \\
\hline \multirow[t]{2}{*}{ Place of residence } & Suburb & 40 & $40.0 \%$ \\
\hline & City & 60 & $60.0 \%$ \\
\hline \multirow[t]{2}{*}{ Income } & Not sufficient & 52 & $52.0 \%$ \\
\hline & Sufficient & 48 & $48.0 \%$ \\
\hline \multirow[t]{3}{*}{ Number of family members } & Small (2-4) & 48 & $48.0 \%$ \\
\hline & Medium (5-7) & 33 & $33.0 \%$ \\
\hline & Large (8 and more) & 19 & $19.0 \%$ \\
\hline \multirow[t]{7}{*}{ Order within family members } & $1 \mathrm{st}$ & 1 & $1.0 \%$ \\
\hline & 2nd & 30 & $30.0 \%$ \\
\hline & $3 \mathrm{rd}$ & 32 & $32.0 \%$ \\
\hline & 4th & 17 & $17.0 \%$ \\
\hline & 5 th & 11 & $11.0 \%$ \\
\hline & 6th & 4 & $4.0 \%$ \\
\hline & 7th or more & 5 & $5.0 \%$ \\
\hline
\end{tabular}

$n=$ frequency, $\%$ = percent, $\mathrm{M}=$ mean, $\mathrm{SD}=$ standard deviation 
only $11 \%$ of them were illiterate or with primary school education. Most of them were single (88\%) and had no job $(73 \%)$. More than half of the participants resided in cities and had insufficient monthly income $(60 \%$ and $52 \%$, respectively). Less than half of the participants (48\%) lived in small families (two to four family members), and almost $62 \%$ of them were the second or third members in the order within their families.

Regarding the history of addiction in the participants, Table 2 shows that the majority of participants (41\%) became addicted to drugs between 2016 and 2020, and almost one-third of them became addicted to drugs between the years 2006 and 2010 (34\%). The majority had a psychotherapy duration of 3-6 months, one to two times admissions to a psychiatric hospital (2.96 average admissions), with no psychiatric or mental illness history among their families $(80 \%, 71 \%$, and $92 \%$, respectively). Participants reported using heroin, cannabis, Strox, Tramadol, and benzodiazepine $(56 \%, 17 \%, 17 \%, 5 \%$, and $5 \%$, respectively). However, no cases of addiction affecting family members were reported in the participant sample.

Table 3 shows the distribution and the mean of the self-compassion scale and its six subscales for the participants. As shown, the vast majority of participants (92\%) had a moderate level of self-compassion, with a mean of

Table 2 Self-reported participant addiction data $(N=100)$

\begin{tabular}{|c|c|c|c|}
\hline Addiction-associated data & & $n$ & $\%$ \\
\hline \multirow[t]{4}{*}{ Onset of the disease categories } & 2005 or before & 11 & $11.0 \%$ \\
\hline & $2006-2010$ & 34 & $34.0 \%$ \\
\hline & $2011-2015$ & 14 & $14.0 \%$ \\
\hline & $2016-2020$ & 41 & $41.0 \%$ \\
\hline \multirow[t]{3}{*}{ Duration of psychotherapy } & $1-3$ months & 14 & $14.0 \%$ \\
\hline & $3-6$ months & 80 & $80.0 \%$ \\
\hline & More than 6 months & 6 & $6.0 \%$ \\
\hline \multirow{5}{*}{$\begin{array}{l}\text { Number of admissions to } \\
\text { the psychiatric hospital }\end{array}$} & 1 time & 30 & $30.0 \%$ \\
\hline & 2 times & 41 & $41.0 \%$ \\
\hline & 3 times & 17 & $17.0 \%$ \\
\hline & 4 times or more & 12 & $12.0 \%$ \\
\hline & $M \pm S D$ & \multicolumn{2}{|c|}{$2.96 \pm 3.79$} \\
\hline \multirow{2}{*}{$\begin{array}{l}\text { Presence of mental illness } \\
\text { in the family }\end{array}$} & No & 92 & $92.0 \%$ \\
\hline & Yes & 8 & $8.0 \%$ \\
\hline \multirow[t]{5}{*}{ Type of narcotic } & Tramadol & 5 & $5.0 \%$ \\
\hline & Strox & 17 & $17.0 \%$ \\
\hline & Heroin & 56 & $56.0 \%$ \\
\hline & Cannabis & 17 & $17.0 \%$ \\
\hline & Benzodiazepine & 5 & $5.0 \%$ \\
\hline \multirow[t]{2}{*}{ Family usage of narcotics } & Yes & 0 & $0.0 \%$ \\
\hline & No & 100 & $100.0 \%$ \\
\hline
\end{tabular}

$n=$ frequency, $\%$ = percent,$M=$ Mean, $S D=$ standard deviation
Table 3 Distribution and the mean of the self-compassion scale and its subscales $(N=100)$

\begin{tabular}{|c|c|c|c|c|}
\hline Self-Compassion Scale & & $n$ & $\%$ & $M \pm S D$ \\
\hline \multirow[t]{3}{*}{ Self-kindness subscale } & Low & 22 & $22.0 \%$ & $2.74 \pm 0.50$ \\
\hline & Moderate & 66 & $66.0 \%$ & \\
\hline & High & 12 & $12.0 \%$ & \\
\hline \multirow[t]{3}{*}{ Self-judgment subscale } & Low & 3 & $3.0 \%$ & $3.22 \pm 0.49$ \\
\hline & Moderate & 52 & $52.0 \%$ & \\
\hline & High & 45 & $45.0 \%$ & \\
\hline \multirow[t]{3}{*}{ Common humanity subscale } & Low & 18 & $18.0 \%$ & $2.79 \pm 0.60$ \\
\hline & Moderate & 43 & $43.0 \%$ & \\
\hline & High & 11 & $11.0 \%$ & \\
\hline \multirow[t]{3}{*}{ Isolation subscale } & Low & 1 & $1.0 \%$ & $3.19 \pm 0.53$ \\
\hline & Moderate & 52 & $52.0 \%$ & \\
\hline & High & 31 & $31.0 \%$ & \\
\hline \multirow[t]{3}{*}{ Mindfulness subscale } & Low & 14 & $14.0 \%$ & $2.83 \pm 0.53$ \\
\hline & Moderate & 72 & $72.0 \%$ & \\
\hline & High & 14 & $14.0 \%$ & \\
\hline \multirow[t]{3}{*}{ Over-identified subscale } & Low & 5 & $5.0 \%$ & $3.26 \pm 0.52$ \\
\hline & Moderate & 59 & $59.0 \%$ & \\
\hline & High & 36 & $36.0 \%$ & \\
\hline \multirow[t]{3}{*}{ Total self-compassion scale } & Low & 1 & $1.0 \%$ & $3.03 \pm 0.18$ \\
\hline & Moderate & 92 & $92.0 \%$ & \\
\hline & High & 7 & $7.0 \%$ & \\
\hline
\end{tabular}

Low 1.00-2.33, moderate $>2.33-3.66$, high $>3.66-5.00$

$n=$ frequency, $\%=$ percent, $M=$ mean, $S D=$ standard deviation

3.03 out of 5 on the Likert scale. The self-compassion subscales were moderate for the majority of the participants, with the highest subscale mean scores reported for the over-identified, self-judgment, and isolation categories (3.26 $\pm 0.52,3.22 \pm 0.49$, and $3.19 \pm 0.53$, respectively).

As shown in Table 4, the majority of respondents (83\%) had a moderate mean score in the spiritual well-

Table 4 Distribution and the mean of the spiritual well-being scale and its subscales $(N=100)$

\begin{tabular}{lllll}
\hline Spirituality Scale & & $\mathbf{n}$ & $\%$ & $\mathbf{M} \pm \mathbf{S D}$ \\
\hline Religious well-being & Low & 11 & $11.0 \%$ & $3.67 \pm 0.87$ \\
& Moderate & 62 & $62.0 \%$ & \\
Existential well-being & High & 27 & $27.0 \%$ & \\
& Low & 0 & $0.0 \%$ & $3.85 \pm 0.52$ \\
& Moderate & 81 & $81.0 \%$ & \\
Total spiritual well-being & High & 19 & $19.0 \%$ & \\
& Low & 0 & $0.0 \%$ & $3.76 \pm 0.56$ \\
& Moderate & 83 & $83.0 \%$ & \\
& High & 17 & $17.0 \%$ & \\
\hline
\end{tabular}

Low 1.00-2.66, moderate $>2.66-4.33$, high $>4.33-6.00$.

$n=$ frequency, $\%=$ percent, $\mathrm{M}=$ mean, $\mathrm{SD}=$ standard deviation 
Table 5 Self-reported drug craving of participants

\begin{tabular}{|c|c|c|c|}
\hline Drug craving & & $n$ & $\%$ \\
\hline \multirow[t]{5}{*}{ The intensity of your feelings of addiction/the extent of your desire to take narcotics during the past $24 \mathrm{~h}$} & Never & 44 & $44.0 \%$ \\
\hline & Mild & 26 & $26.0 \%$ \\
\hline & Moderate & 22 & $22.0 \%$ \\
\hline & Strong & 5 & $5.0 \%$ \\
\hline & Very strong & 3 & $3.0 \%$ \\
\hline \multirow[t]{5}{*}{ Addiction rate/how many times you wanted to take narcotics during the past $24 \mathrm{~h}$} & Never & 50 & $50.0 \%$ \\
\hline & Probably not & 22 & $22.0 \%$ \\
\hline & Many times, & 18 & $18.0 \%$ \\
\hline & Regularly & 8 & $8.0 \%$ \\
\hline & Continuously & 2 & $2.0 \%$ \\
\hline \multirow[t]{5}{*}{ The length of time you wanted to take narcotics during the past $24 \mathrm{~h}$} & Never & 49 & $49.0 \%$ \\
\hline & Very short period & 22 & $22.0 \%$ \\
\hline & Short period & 16 & $16.0 \%$ \\
\hline & To some extent & 10 & $10.0 \%$ \\
\hline & Long time & 3 & $3.0 \%$ \\
\hline \multirow[t]{3}{*}{ Mention the number of times you wanted to take narcotics } & None & 59 & $59.0 \%$ \\
\hline & One time & 17 & $17.0 \%$ \\
\hline & Two times & 23 & $23.0 \%$ \\
\hline
\end{tabular}

$n=$ frequency, $\%=$ percent

Table 6 Difference in the mean scores of Self-Compassion Scale based on the sociodemographic and clinical data ( $N=100)$

\begin{tabular}{|c|c|c|c|c|}
\hline Personal characteristics & & Mean rank & Test & $P$ value \\
\hline \multirow[t]{3}{*}{ Age category } & $20-29$ & 50.6 & \multirow{3}{*}{$\begin{array}{l}\text { Kruskal-Wallis test } \\
\text { Chi-square }=5.441\end{array}$} & \multirow[t]{3}{*}{0.066} \\
\hline & $30-39$ & 45.9 & & \\
\hline & 40 and over & 70.1 & & \\
\hline \multirow[t]{2}{*}{ Gender } & Male & 50 & \multirow[t]{2}{*}{ Mann-Whitney $U=96$} & \multirow[t]{2}{*}{0.338} \\
\hline & Female & 67 & & \\
\hline \multirow[t]{2}{*}{ Marital status } & Single & 53 & \multirow[t]{2}{*}{ Mann-Whitney $U=371$} & \multirow[t]{2}{*}{0.096} \\
\hline & Married & 64 & & \\
\hline \multirow[t]{2}{*}{ Occupation } & No Job & 50 & \multirow[t]{2}{*}{ Mann-Whitney $U=927$} & \multirow[t]{2}{*}{0.65} \\
\hline & Has a Job & 53 & & \\
\hline \multirow[t]{5}{*}{ Education } & Illiterate & 49 & \multirow{5}{*}{$\begin{array}{l}\text { Kruskal-Wallis test } \\
\text { Chi-square }=2.085\end{array}$} & \multirow[t]{5}{*}{0.721} \\
\hline & Primary school & 35 & & \\
\hline & Secondary school & 49 & & \\
\hline & High school & 51 & & \\
\hline & University education & 55 & & \\
\hline \multirow[t]{2}{*}{ Place of residence } & Suburb & 54 & \multirow[t]{2}{*}{ Mann-Whitney $U=1071$} & \multirow[t]{2}{*}{0.366} \\
\hline & City & 49 & & \\
\hline \multirow[t]{2}{*}{ Income } & Not Sufficient & 52 & \multirow[t]{2}{*}{ Mann-Whitney $U=1153$} & \multirow[t]{2}{*}{0.514} \\
\hline & Sufficient & 48 & & \\
\hline \multirow[t]{2}{*}{ Presence of mental illness in the family } & No & 51 & \multirow[t]{2}{*}{ Mann-Whitney $U=284$} & \multirow[t]{2}{*}{0.286} \\
\hline & Yes & 42 & & \\
\hline \multirow[t]{5}{*}{ Type of narcotic } & Tramadol & 62 & \multirow{5}{*}{$\begin{array}{l}\text { Kruskal-Wallis test } \\
\text { Chi-square }=1.595\end{array}$} & \multirow[t]{5}{*}{0.810} \\
\hline & Strox & 49 & & \\
\hline & Heroin & 49 & & \\
\hline & Cannabis & 54 & & \\
\hline & Benzodiazepine & 46 & & \\
\hline
\end{tabular}


being scale (mean score: $3.76 \pm 0.56$ out of 6 on the Likert scale) and in both the religious and existential well-being subscales (mean scores: $3.67 \pm 0.87$ and 3.85 \pm 0.52 , respectively).

Regarding drug craving in the participants, Table 5 shows that more than two-thirds (70\%) of the participants reported that they had none or mild feelings of intensity and desire to take narcotics during the past $24 \mathrm{~h}$. They had a minimal addiction rate $(10 \%)$ as indicated by the times in which the participants indicated continuously or regularly wanting to take narcotics in the past $24 \mathrm{~h}$, and they had none or relatively very short desire to take narcotics period during the past $24 \mathrm{~h}(71 \%)$. The reported frequency in which the participants wanted to take narcotics was zero or just one time during the last $24 \mathrm{~h}(76 \%)$.

The sample of participants was neither large nor random; however, the findings of the nonparametric tests revealed no significant differences in mean scores of Self-Compassion Scale (Table 6), Spiritual Well-Being Scale (Table 7), and Craving Scale (Table 8) based on the participants' sociodemographic characteristics and some addiction associated clinical data.

Concerning the correlation among the self-compassion scale and its subscales for participants, Table 9 indicates a positive correlation between all self-compassion subscales and the self-compassion main scale, with a significant correlation found with the self-judgment, isolation, mindfulness, and over-identified subscales. Also, there were various positive and negative significant correlations among the self-compassion subscales, reflecting that half of the subscales ( 3 out of 6) were inverted in coding since they consisted of negative statements $(p<$ $0.01)$.

Table 10 shows the correlations between the spiritual well-being scale and its subscales. As shown, there was a significant positive correlation between the spiritual well-being scale and both the religious well-being and existential well-being subscales $(p<0.001)$. Additionally, there was a significant positive correlation between the religious well-being and existential well-being subscales $(p<0.05)$.

Table 7 Difference in the mean scores of Spiritual Well-Being Scale based on the sociodemographic and clinical data ( $N=100)$

\begin{tabular}{|c|c|c|c|c|}
\hline Personal characteristics & & Mean rank & Test & $P$ value \\
\hline \multirow[t]{3}{*}{ Age category } & $20-29$ & 45 & \multirow{3}{*}{$\begin{array}{l}\text { Kruskal-Wallis test } \\
\text { Chi-square }=3.971\end{array}$} & \multirow[t]{3}{*}{0.137} \\
\hline & $30-39$ & 57 & & \\
\hline & 40 and over & 48 & & \\
\hline \multirow[t]{2}{*}{ Gender } & Male & 50 & \multirow[t]{2}{*}{ Mann-Whitney $U=106$} & \multirow[t]{2}{*}{0.450} \\
\hline & Female & 42 & & \\
\hline \multirow[t]{2}{*}{ Marital status } & Single & 53 & \multirow[t]{2}{*}{ Mann-Whitney $U=440$} & \multirow[t]{2}{*}{0.060} \\
\hline & Married & 42 & & \\
\hline \multirow[t]{2}{*}{ Occupation } & No job & 50 & \multirow[t]{2}{*}{ Mann-Whitney $U=965$} & \multirow[t]{2}{*}{0.877} \\
\hline & Has a job & 49 & & \\
\hline \multirow[t]{5}{*}{ Education } & Illiterate & 36 & \multirow{5}{*}{$\begin{array}{l}\text { Kruskal-Wallis test } \\
\text { Chi-square }=6.895\end{array}$} & \multirow[t]{5}{*}{0.142} \\
\hline & Primary school & 40 & & \\
\hline & Secondary school & 47 & & \\
\hline & High school & 50 & & \\
\hline & University education & 52 & & \\
\hline \multirow[t]{2}{*}{ Place of residence } & Suburb & 50 & \multirow[t]{2}{*}{ Mann-Whitney $U=1182$} & \multirow[t]{2}{*}{0.899} \\
\hline & City & 51 & & \\
\hline \multirow[t]{2}{*}{ Income } & Not Sufficient & 42 & \multirow[t]{2}{*}{ Mann-Whitney $U=857$} & \multirow[t]{2}{*}{0.314} \\
\hline & Sufficient & 51 & & \\
\hline \multirow[t]{2}{*}{ Presence of mental illness in the family } & No & 49 & \multirow[t]{2}{*}{ Mann-Whitney $U=289.5$} & \multirow[t]{2}{*}{0.318} \\
\hline & Yes & 60 & & \\
\hline \multirow[t]{5}{*}{ Type of narcotic } & Tramadol & 33 & \multirow{5}{*}{$\begin{array}{l}\text { Kruskal-Wallis test } \\
\text { Chi-square }=9.373\end{array}$} & \multirow[t]{5}{*}{0.058} \\
\hline & Strox & 47 & & \\
\hline & Heroin & 57 & & \\
\hline & Cannabis & 40 & & \\
\hline & Benzodiazepine & 45 & & \\
\hline
\end{tabular}


Table 8 Difference in the mean scores of Craving Scale based on the sociodemographic and clinical data $(N=100)$

\begin{tabular}{|c|c|c|c|c|}
\hline Personal characteristics & & Mean rank & Test & $P$ value \\
\hline \multirow[t]{3}{*}{ Age category } & $20-29$ & 53 & \multirow{3}{*}{$\begin{array}{l}\text { Kruskal-Wallis test } \\
\text { Chi-square }=1.525\end{array}$} & \multirow[t]{3}{*}{0.466} \\
\hline & 30-39 & 46 & & \\
\hline & 40 and over & 53 & & \\
\hline \multirow[t]{2}{*}{ Gender } & Male & 50 & \multirow{2}{*}{$\begin{array}{l}\text { Mann-Whitney } U= \\
128\end{array}$} & \multirow[t]{2}{*}{0.746} \\
\hline & Female & 56 & & \\
\hline \multirow[t]{2}{*}{ Marital status } & Single & 55 & \multirow[t]{2}{*}{ Mann-Whitney $U=350$} & \multirow[t]{2}{*}{0.078} \\
\hline & Married & 69 & & \\
\hline \multirow[t]{2}{*}{ Occupation } & No Job & 48 & \multirow[t]{2}{*}{ Mann-Whitney $U=793$} & \multirow[t]{2}{*}{0.122} \\
\hline & Has a Job & 57 & & \\
\hline \multirow[t]{5}{*}{ Education } & Illiterate & 55 & \multirow{5}{*}{$\begin{array}{l}\text { Kruskal-Wallis test } \\
\text { Chi-square = } 4.395\end{array}$} & \multirow[t]{5}{*}{0.355} \\
\hline & Primary school & 57 & & \\
\hline & Secondary school & 52 & & \\
\hline & High school & 48 & & \\
\hline & University education & 46 & & \\
\hline \multirow[t]{2}{*}{ Place of residence } & Suburb & 53 & \multirow[t]{2}{*}{ Mann-Whitney $U=1124$} & \multirow[t]{2}{*}{0.589} \\
\hline & City & 49 & & \\
\hline \multirow[t]{2}{*}{ Income } & Not Sufficient & 56 & \multirow[t]{2}{*}{ Mann-Whitney $U=848$} & \multirow[t]{2}{*}{0.224} \\
\hline & Sufficient & 47 & & \\
\hline \multirow[t]{2}{*}{ Presence of mental illness in the family } & No & 51 & \multirow[t]{2}{*}{ Mann-Whitney $U=301$} & \multirow[t]{2}{*}{0.377} \\
\hline & Yes & 44 & & \\
\hline \multirow[t]{5}{*}{ Type of narcotic } & Tramadol & 64 & \multirow{5}{*}{$\begin{array}{l}\text { Kruskal-Wallis test } \\
\text { Chi-square }=8.067\end{array}$} & \multirow[t]{5}{*}{0.089} \\
\hline & Strox & 54 & & \\
\hline & Heroin & 49 & & \\
\hline & Cannabis & 59 & & \\
\hline & Benzodiazepine & 50 & & \\
\hline
\end{tabular}

For the correlation between the self-compassion scale, spiritual well-being scale, and the drug craving scale for participants, Table 11 indicated a significant inverse correlation between the drug craving scale and both the self-compassion scale $(p<0.05)$ and the spiritual wellbeing scale $(p<0.001)$. However, there was a nonsignificant positive correlation between the selfcompassion scale and the spiritual well-being scale ( $p=$ 0.613).

\section{Discussion}

Craving is a key addiction trait that predicts treatment outcomes and has been added as a criterion for diagnosing substance use disorders in the DSM-5, as cited by Preston et al. [23]. Understanding the factors that influence cravings will enhance the outcome of treatment and help patients avoid relapse; these factors include self-compassion and spiritual well-being. Hence, this study aimed to explore the relationship between selfcompassion, spiritual well-being, and craving. In this study, more than half of the study participants (55\%) were young people (20-29 years) with a mean age of $29.21 \pm 7.49$ years. More than half $(56 \%)$ were dependent on heroin and the majority of participants have received 3-6 months of psychotherapy.

These results were consistent with Mahjoub et al. [24] who reported that drug dependence was significantly higher among individuals between the ages of 18 and 25 years $(44 \%)$ compared to individuals between the ages of 26 and 40. For heroin users, the average age when using heroin for the first time was 19.67 years. Kumar et al. [25] reported that $7 \%$ of heroin users began using heroin before the age of 16 years, and about $83 \%$ of them began using heroin between the ages of 16 and 24 years.

Our results showed that cravings and self-compassion have a strong negative correlation. These results are consistent with other scientific studies by Gilbert [26], Gilbert [27], Iskandar, Akin [28] and Neff et al. [29], Raes [30], Shapira and Mongrain [31], and Shapiro et al. [32]. These studies reported that cravings were negatively related to self-compassion and were positively related to selfjudgment. Likewise, Gilbert [27] acknowledged that few 


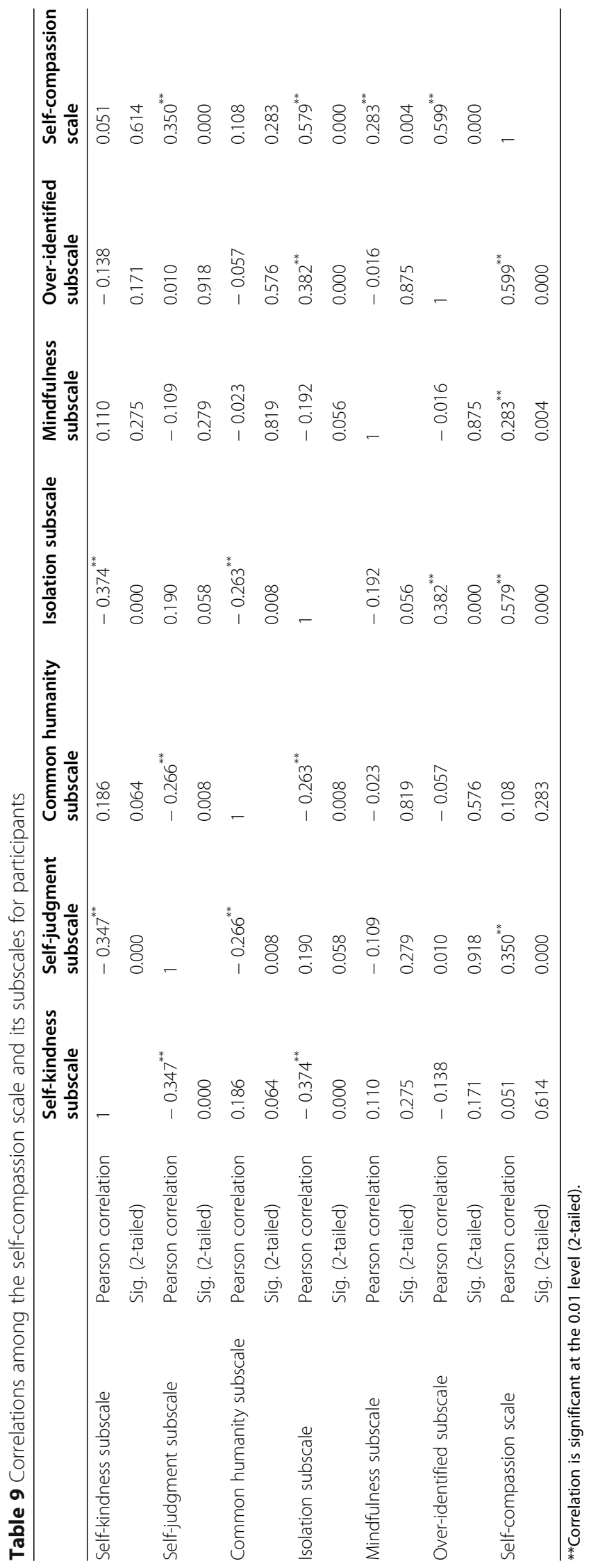


Table 10 Correlation between the spiritual well-being scale and its subscales for participants

\begin{tabular}{lllll}
\hline & & Religious well-being subscale & Existential well-being subscale & Total spiritual scale \\
\hline Religious well-being subscale & Pearson correlation & 1 & $0.252^{*}$ & $0.893^{* *}$ \\
& Sig. (2-tailed) & & 0.011 & 0.000 \\
Existential well-being subscale & Pearson correlation & $0.252^{*}$ & 1 & $0.660^{* *}$ \\
& Sig. (2-tailed) & 0.011 & & 0.000 \\
Total spiritual scale & Pearson correlation & $0.893^{* *}$ & $0.660^{* *}$ & 1 \\
& Sig. (2-tailed) & 0.000 & 0.000 & \\
\hline
\end{tabular}

*Correlation is significant at the 0.05 level (2-tailed).

**Correlation is significant at the 0.01 level (2-tailed).

studies have explored the relationships between compassion and drug use (e.g., Rendon, 2006; Brooks et al., 2012).

Rendon [33] identified a significant negative association between alcohol and self-compassion for 300 undergraduate psychology students. Alcohol abuse was negatively associated with self-esteem, self-compassion, and psychological symptoms [34]. Phelps et al. [35] additionally, found that self-compassion can be associated with substance use disorder and risk factors that lead to addiction.

Our findings showed that there was a significant negative correlation between drug cravings and spiritual well-being among participants. These results were consistent with Heinz et al. [36] who reported that spirituality was an important and independent predictor of recovery and /or improvement in treatment outcome indicators. Spirituality also positively correlated with the length of sobriety, while adherence to a higher strength can reduce the severity of recurring episodes. In retrospective studies, recovering addicts frequently mentioned spirituality and religiosity as important components of recovery efforts that were helpful in maintaining the changes made during treatment.

Weiss-Ogden [37] has demonstrated a link between spiritual well-being and other dimensions of well-being, including recovery from illness, treatment of psychological symptoms, and maintenance of recovery from substance use disorders (SUDs).
Our findings revealed that the majority of participants had a moderate level of self-compassion and spiritual well-being, with the highest level of self-compassion and well-being for over-identification, self-judgment, and isolation. Likewise, Phelps et al. [35] found that the risk of developing SUD was associated with the sub-scale of isolation and self-compassion. This is consistent with previous studies in which intimate relationships were more complex for individuals with low self-compassion [38].

Basharpur et al. [39] reported that people with negative self-judgment constantly engage in rumination and self-criticism, focusing on the negative aspects that increase craving in drug-dependent people. In short, selfcompassion can protect individuals from negative consequences. Participants with low SUDs risk also had higher degrees of mindfulness and lower degrees of autonomy compared to their high-risk counterparts. This aligns with the belief that people with strong self-compassion should use inner skills to deal with pain without selfjudgment, such as empathy, awareness, tolerance, and forgiveness [40]. There is currently evidence that individuals' perception, a feature of self-compassion, helps protect against relapse [41].

Brooks et al. [34] found that sample participants scored significantly lower on common humanity, self-kindness, and mindfulness compared to the general population. Excessive self-identification, perceived isolation, and selfjudgment were also significantly higher in participants than standard scores in the general population.

Table 11 Correlation between the self-compassion scale, spiritual well-being scale, and drug craving scale for participants

\begin{tabular}{lllll}
\hline & & Self-compassion scale & Spiritual well-being scale & Drug craving scale \\
\hline Self-compassion scale & Pearson correlation & 1 & 0.051 & $-0.210^{*}$ \\
& Sig. (2-tailed) & & 0.613 & 0.036 \\
Spiritual well-being scale & Pearson correlation & 0.051 & 1 & $-0.631^{* *}$ \\
& Sig. (2-tailed) & 0.613 & & 0.000 \\
Drug craving scale & Pearson correlation & $-0.210^{*}$ & $-0.631^{* *}$ & 1 \\
& Sig. (2-tailed) & 0.036 & 0.000 & \\
\hline
\end{tabular}

${ }^{*}$ Correlation is significant at the 0.05 level (2-tailed)

** Correlation is significant at the 0.01 level (2-tailed) 


\section{Conclusions}

In conclusion, more than half of individuals with drug addiction were young, with the vast majority of them being single males with no job or sufficient income. The vast majority of participants had a moderate level of selfcompassion as reflected on the self-compassion scale. The majority of respondents also had a moderate spiritual well-being level in terms of both religious and existential well-being, as shown using the spiritual well-being scale. Regarding drug craving, more than two-thirds of the participants reported that they had no or just mild addiction feelings intensity, or desire to take narcotics during the past $24 \mathrm{~h}$.

There was a positive correlation between all selfcompassion subscales and the self-compassion main scale. Additionally, there was a significant positive correlation between the spiritual well-being scale and both the religious well-being and the existential well-being subscales. In contrast, there was a significant negative correlation between the drug craving scale and both the self-compassion scale and the spiritual well-being scale.

\section{Recommendations}

The use of national-wide orientation or educational programs about drug addiction and the negative consequences of addiction utilizing social and mass media should be a high priority, especially for the young population. Similarly, the government is responsible to make job opportunities available for individuals, which may have a positive effect in reducing the chances of drug addiction.

Focusing on demonstrating the importance of life to people with substance use disorders and for concerned people or family, self-love, meaning-of-life awareness, and socialization are highly recommended. All of these factors will help individuals improve their self-esteem and self-compassion. Focusing on developing religious practices and existential well-being is likely to improve people's spiritual well-being as well. Improving individuals' spiritual well-being and enhancing self-compassion will have significant effects on reducing cravings for drug abuse and addiction.

\section{Limitations}

The use of cross-sectional research design and convenience sampling techniques are not ideal research designs. The use of in-depth longitudinal design and random sampling techniques, including participants from more hospitals, is highly recommended for future research.

\section{Abbreviations}

BSCS: Brief Substance Craving Scale: SCS. Self-Compassion Scale: SUDs: Substance use disorders; SWBS: Spiritual Well-Being Scale

\section{Acknowledgments}

The researchers would like to acknowledge the administration of the psychiatric department at Mansoura University Hospital for their cooperation in conducting this research. This work is dedicated to the victims of drug addiction around the world.

\section{Authors' contributions}

MAS is the corresponding author and contributed to the design and submission of the research. SAH collected the data and contributed to the implementation. SMT contributed to the analysis of the results and the writing of the manuscript. All authors participated in the preparation, editing and approval of the final manuscript.

\section{Funding}

No funding or support was obtained for this research.

\section{Availability of data and materials}

The present study data sets are available from the corresponding author on reasonable request.

\section{Declarations}

\section{Ethics approval and consent to participate}

All ethical considerations related to scientific research in humans have been taken into account in accordance with the Declaration of Helsinki [22]. Written consent was obtained from all participants in the current study; also, the research ethics committee at the Faculty of Nursing at Mansoura University approved to conduct the current research (Ethics committee approval, Ref. No. P. 0210).

\section{Consent for publication}

Not applicable.

\section{Competing interests}

The researchers declare that there are no conflicts of interest associated with this research work

\section{Author details}

${ }^{1}$ Nursing Department, Mohammed Al-Mana College for Medical Science, Dammam, Saudi Arabia. ${ }^{2}$ Faculty of Nursing, Mansoura University, Mansoura, Egypt.

Received: 30 April 2021 Accepted: 25 July 2021

Published online: 10 September 2021

\section{References}

1. McLellan AT (2017) Substance misuse and substance use disorders: why do they matter in healthcare? Transactions of the American Clinical and Climatological Association 128:112-130

2. Da Silva Roggi PM, Da Gama MFN, Neves FS, Garcia F (2015) Update on treatment of craving in patients with addiction using cognitive behavioral therapy. Clinical Neuropsychiatry 12(5):118-127

3. Rabie M, Shaker NM, Gaber E, el-Habiby M, Ismail D, el-Gaafary M, Lotfy A, Sabry N, Khafagy W, Muscat R (2020) Prevalence updates of substance use among Egyptian adolescents. Middle East Current Psychiatry 27(1):4. https:// doi.org/10.1186/s43045-019-0013-8

4. Hamdi E, Sabry N, Sedrak A, Khowailed A, Loza N, Rabie M, Ramy H (2016) Sociodemographic indicators for substance use and abuse in Egypt. Journal of Addiction \& Prevention 4(1):8

5. Oliveira ALCBd, Feitosa CDA, Santos AGd, Lima LAdA, Fernandes MA, Monteiro CFdS (2017) Spirituality and religiosity in the context of drug abuse. Rev Rene 18(2):283-Rev R290. https://doi.org/10.15253/2175-6783.201 7000200019

6. Sheykhnezhad F, Seyedfatemi N (2019) Effect of group education on selfefficacy and craving tendencies in drug abusers in 5th Azar Drug Abuse Treatment Center of Gorgan. Cogent Psychol 6(1):1587818. https://doi.org/1 0.1080/23311908.2019.1587818

7. Minervini I, Palandri S, Bianchi S, Bastiani L, Paffi D (2011) Desire and coping self-efficacy as craving measures in addiction: the self-efficacy and desire scale (SAD). The Open Behavioral Science Journal 5(1):1-7. https://doi.org/1 $0.2174 / 1874230001105010001$ 
8. JLd S, Vecchia MD (2018) The will in Vygotsky: contributions to the understanding of the "craving" in drug addiction. Psicologia USP 29(2):200211. https://doi.org/10.1590/0103-656420160189

9. Garner AR, Gilbert SE, Shorey RC, Gordon KC, Moore TM, Stuart GL (2020) A longitudinal investigation on the relation between self-compassion and alcohol use in a treatment sample: a brief report. Substance Abuse 14:1-5. https://doi.org/10.1177/1178221820909356

10. Chen $\mathrm{G}$ (2019) The role of self-compassion in recovery from substance use disorders. OBM Integrative and Complementary Medicine 4(2):1-17. https:// doi.org/10.21926/obm.icm.1902026

11. Neff K, Germer C (2017) Self-compassion and psychological well-being. The Oxford handbook of compassion science, Chap 27 Oxford University Press 371-385

12. Douaihy A, Singh N (2001) Factors affecting quality of life in patients with HIV infection. The AIDS Reader 11(9):450-454, 460-451, 475

13. Salmabadi M, Sadeghbojd MF, Farshad MR, Zolfaghari S (2016) Comparing the spiritual health and quality of life in addicted and non-addicted patients in the city of Birjand, Iran. Int J High Risk Behav Addict 5(1):e23208. https:// doi.org/10.5812/ijhrba.23208

14. Zerbetto SR, AMdS G, Santile N, SAF G, Acorinte AC, Giovannetti G (2017) Religiosity and spirituality: mechanisms of positive influence on the life and treatment of alcoholics. Escola Anna Nery 21(1):e20170005. https://doi.org/1 0.5935/1414-8145.20170005

15. Somoza E, Dyrenforth S, Goldsmith J, Mezinskis J, Cohen M (1995) In: annual meeting of the American Psychiatric Association. In: In search of a universal drug craving scale. Miami, FL, pp 20-25

16. Ellison CW (1983) Spiritual well-being: Conceptualization and measurement. Journal of Psychology and Theology 11(4):330-338. https://doi.org/10.1177/ 009164718301100406

17. Musa AS, Pevalin DJ (2012) An Arabic version of the spiritual well-being scale. The International Journal for the Psychology of Religion 22(2):119134. https://doi.org/10.1080/10508619.2011.638592

18. Musa AS, Pevalin DJ (2014) Psychometric evaluation of the Arabic version of the Spiritual Well-Being Scale on a sample of Jordanian Arab Christians. Journal of Psychology and Theology 42(3):293-301. https://doi.org/10.1177/ 009164711404200306

19. Neff KD (2003) The development and validation of a scale to measure self-compassion Self and Identity 2(3):223-250. https:/doi.org/10.1080/15298860390209035

20. Hacheem KA (2018) Motivational beliefs and its relation with the psychological well-being and self-compassion among university students. University of Baghdad

21. IBM Corp (2019) IBM SPSS Statistics for Windows, Version 26.0. Armonk: IBM Corp.

22. World Medical Association (2018) WMA declaration of HELSINKI - ethical principles for medical research involving human subjects. https://www.wma net/policies-post/wma-declaration-of-helsinki-ethical-principles-for-medicalresearch-involving-human-subjects/

23. Preston KL, Kowalczyk WJ, Phillips KA, Jobes ML, Vahabzadeh M, Lin JL, Mezghanni M, Epstein DH (2018) Exacerbated craving in the presence of stress and drug cues in drug-dependent patients. Neuropsychopharmacology 43(4):859-867. https://doi.org/10.1038/npp.201 7.275

24. Mahgoub RM, El-Hadidy MA, El Hoda MFA, Atrouny MH (2016) A study of opioid dependence among Mansoura University students. The Egyptian Journal of Psychiatry 37(3):174-179. https://doi.org/10.4103/1110-1105.195548

25. Kumar S, Wairagkar N, Mahanta J, Satyanarayana K, Chetial M, Phukan R, Goswami S (1996) Profile of heroin addicts in Nagaland, India. The Southeast Asian Journal of Tropical Medicine and Public Health 27(4):768-771

26. Gilbert P (2009) Introducing compassion-focused therapy. Advances in Psychiatric Treatment 15(3):199-208. https:/doi.org/10.1192/apt.bp.107.005264

27. Gilbert SE (2014) Using mindful self-compassion to improve self-criticism, self-soothing, cravings, and relapse in substance abusers in an intensive outpatient program. University of Tennessee - Knoxville

28. Iskender M, Akin A (2011) Self-compassion and Internet addiction. Turkish Online Journal of Educational Technology-TOJET 10(3):215-221

29. Neff KD, Hsieh Y-P, Dejitterat K (2005) Self-compassion, achievement goals, and coping with academic failure. Self and Identity 4(3):263-287. https://doi. org/10.1080/13576500444000317

30. Raes $F$ (2011) The effect of self-compassion on the development of depression symptoms in a non-clinical sample. Mindfulness 2(1):33-36. https://doi.org/10.1007/s12671-011-0040-y
31. Shapira LB, Mongrain M (2010) The benefits of self-compassion and optimism exercises for individuals vulnerable to depression. The Journal of Positive Psychology 5(5):377-389. https://doi.org/10.1080/17439760.2010.51 6763

32. Shapiro SL, Astin JA, Bishop SR, Cordova M (2005) Mindfulness-based stress reduction for health care professionals: results from a randomized trial. International Journal of Stress Management 12(2):164-176. https://doi.org/1 $0.1037 / 1072-5245.12 .2 .164$

33. Rendon KP (2006) Understanding alcohol use in college students: a study of mindfulness, self-compassion, and psychological symptoms. University of Texas, Austin, TX

34. Brooks M, Kay-Lambkin F, Bowman J, Childs S (2012) Self-compassion amongst clients with problematic alcohol use. Mindfulness 3(4):308-317. https://doi.org/10.1007/s12671-012-0106-5

35. Phelps CL, Paniagua SM, Willcockson IU, Potter JS (2018) The relationship between self-compassion and the risk for substance use disorder. Drug and Alcohol Dependence 183:78-81. https://doi.org/10.1016/j.drugalcdep.2017.1 0.026

36. Heinz AJ, Disney ER, Epstein DH, Glezen LA, Clark PI, Preston KL (2010) A focus-group study on spirituality and substance-user treatment. Substance Use \& Misuse 45(1-2):134-153. https://doi.org/10.3109/10826080903035130

37. Weiss-Ogden KR (2014) The relationship between trauma and spiritual wellbeing of women with substance use disorders. East Carolina University, Department of Addictions and Rehabilitation Studies Doctoral Dissertation

38. Yarnell LM, Neff KD (2013) Self-compassion, interpersonal conflict resolutions, and well-being. Self and Identity 12(2):146-159. https://doi.org/1 $0.1080 / 15298868.2011 .649545$

39. Basharpoor S, Khosravinia D, Atadokht A, Daneshvar S, Narimani M, Massah O (2014) The role of self-compassion, cognitive self-control, and illness perception in predicting craving in people with substance dependency. Journal of Practice in Clinical Psychology 2(3):155-164

40. Germer CK, Neff KD (2013) Self-compassion in clinical practice. Journal of Clinical Psychology 69(8):856-867. https://doi.org/10.1002/jclp.22021 Epub 2013 Jun 17

41. Bowen S, Chawla N, Marlatt GA (2011) Mindfulness-based relapse prevention for addictive behaviors: A clinician's guide. Guilford Press

\section{Publisher's Note}

Springer Nature remains neutral with regard to jurisdictional claims in published maps and institutional affiliations.

\section{Submit your manuscript to a SpringerOpen ${ }^{\circ}$ journal and benefit from:}

- Convenient online submission

- Rigorous peer review

- Open access: articles freely available online

High visibility within the field

- Retaining the copyright to your article

Submit your next manuscript at $>$ springeropen.com 